\title{
ADOPTION OF CELL PHONES AS PREPAREDNESS EFFORTS FOR NATURAL DISASTERS
}

\author{
Assion Lawson-Body, University of North Dakota, alawsonbody@business.und.edu \\ Lori Willoughby, Minot State University, lori.willoughby@minotstateu.edu \\ Laurence Mukankusi, University of North Dakota, Imukankusi@business.und.edu \\ Kinvi Logossah, University of Antilles and Guyana, K.logossah@yahoo.fr
}

\begin{abstract}
In recent years, a number of cell phone adoption studies have been conducted. However, these studies did not consider cell phones adoption in developing countries where natural disasters frequently occur. This omission is surprising because the preparedness literature leads us to conclude cell phone adoption can be useful. The goal of this study is to investigate the adoption of cell phones as preparedness efforts during the natural disaster seasons in Haiti. Data was collected through interviews involving 24 students from Haiti who live in natural disaster zones. Some preparedness factors influencing cell phone adoption were found: user previous disaster experience, user perceived responsibility for preparedness and user disaster related anxiety. Some innovative characteristics influencing cell phone adoption also were found: perceived relative advantage for preparedness, perceived compatibility for preparedness, perceived complexity for preparedness, subjective norms for preparedness and perceived risks for preparedness.
\end{abstract}

Keywords: Preparedness, Natural Disasters, IT Adoption, Cell phone, Developing countries.

\section{INTRODUCTION}

In the year 2002 alone, disasters affected a staggering 608 million people worldwide [16]. Natural disasters include bring earthquakes, flooding, droughts, heat waves, cold spells and events that destroy countries, businesses and individual property and well-being [22]. Because of the damages and substantial economic losses cause by natural disasters [14], many studies agree that preparedness plan and efforts should be put in place in order to minimize those damages. Therefore, preparedness for natural disasters has been a topic for a growing study. Emergency preparedness and response are complex tasks that depend on organizational and inter-organizational structure [12]. The recovery after a natural disaster is related to its management, which depends on the effectiveness of preparedness [12].

Many studies proposed factors to be considered to minimize damages and pave the way for recovery actions $[14,12]$. However, the adoption of technology as a factor was omitted. More specifically, the adoption of cell phones as part of preparedness for natural disasters has been left aside. This omission is surprising because the preparedness literature leads us to conclude cell phone adoption can be useful. In recent years, a number of cell phone adoption studies have been conducted in developed countries and developing countries. This is because, an increasing number of people use cell phones on a daily basis in the world [9]. However, these studies did not consider cell phones adoption in developing countries where natural disasters frequently occur. This study is dedicated to fill this gap in literature. The goal of this study is to investigate the adoption of cell phones as preparedness efforts during the natural disaster seasons in a developing country. Since Haiti is a country vulnerable to natural disasters, the present study aims to investigate the adoption of cell phones for natural disaster preparedness. The relationship between individual preparedness and intension to adopt cell phones will be explored.

\section{THEORETICAL BACKGROUND}

An understanding of the adoption of cell phones as preparedness efforts for natural disasters in Haiti is informed by two theoretical frameworks: preparedness theory and the diffusion of innovation theory (DOI). 


\section{Issues in Information Systems}

Volume 13, Issue 2, pp. 11-20, 2012

Both theoretical frameworks come from socio- psychological theories of human behavior such as Theory of Reasoned Action (TRA) and Theory of Planned Behavior (TPB). In addition, the preparedness theory comes from socio-demographic theorists.

\section{Preparedness theory}

Preparedness is a social science phenomenon which consists of the state of response readiness established by decisions and actions executed in advance of a natural disaster [3]. Preparedness encompasses planning activities that should be undertaken in case of natural disasters. Individuals are intended to execute those planning activities to survive and to quickly recover.

Planning activities include: creating a meeting plan, knowing shelter location, having a water purification system, having a waste handling system, having a dish washing system, and having a food plan (personal food and water supplies, foodstuffs - non- perishable foods - that can be stored without refrigeration that are easy to consume without preparation) [4]. In addition, the importance of information flow has been recognized in many emergency preparedness booklets. The right information at the right time can allow the population to be prepared and equipped to act correctly [4]. The population should know which entity is the official source of information and how that information is distributed [4].

Mileci et al [14] have reviewed factors that promote and motivate the adoption of protective measures among persons who live in high-risk zones. They organized those factors in two categories: socio-demographic factors of the persons (age, marital status, presence of children living at home, income, education, home ownership, and length of residence at the same location) and psychological factors of the persons (previous disaster experience, personality characteristics, self-efficacy, causal attributions, perceived responsibility for preparedness and amount of concern or preoccupation for a future catastrophe). Also, Manca and Brambilla [12] identify physical, individual and contextual factors that influence an effective preparedness strategy. The physical factors deal with vehicles and equipment. Vehicles can be used to move from a natural disaster zone to a safer area. For example, many people did not leave New Orleans (USA) before Hurricane Katrina because they did not have vehicles. Equipment like hammers and shovels can be used to rescue people stuck under wreckage in the aftermath of natural disasters. The contextual factors are the resources available in the country or the region. For example, in some rich countries, the buildings follow anti-earthquake standards. This can minimize the damage caused by natural disasters. The individual factors consist of the role and the responsibility of the person in the community or the country. For example, community leaders usually receive information first.

Tompkins [22] finds that self-efficacy, strong local and international support networks, combined with a willingness to act collectively and to learn from mistakes appear to be part of preparedness factors for natural disasters in different parts of the World. After conducting telephone interviews with 1200 Florida households to ask about current levels of preparedness in hurricane seasons, Baker [1] found that preparedness was strongly related to factors like income level, home ownership, race, age, and type of housing.

\section{The Diffusion of Innovation Theory (DOI)}

Rogers [18] distinguishes five innovation characteristics that influence the intention to adopt IT: relative advantage, compatibility, complexity, triability and observability. These characteristics can be considered in relation to individual cell phone adoption for natural disasters preparedness because Rogers [18] DOI focuses on individual level of adoption of IT. Tornatzky and Klein [23] found that only three of the five innovation characteristics are related to technology adoption. Therefore, in this study we replaced triability and observability with subjective norms and perceived risk. Venkatesh and Davis (2000) have theorized that subjective norms positively influence an individual's technology adoption behavior [10]. Lee [11] has considered perceived risk as an additional dimension in diffusion and adoption of innovation. 


\section{Issues in Information Systems}

Volume 13, Issue 2, pp. 11-20, 2012

Relative advantage is the extent to which an innovation is superior to the technology it is replacing $[8,18]$. Perceived compatibility is the extent to which an innovation fits easily into the values and routine of an individual $[8,18]$. Perceived complexity is defined as the degree to which an innovation is perceived as relatively difficult to understand and use [18]. Subjective norms refer to a person's perception that most people who are important to him think he should or should not perform the behavior in question [10]. Perceived risk is the possible expected loss or damage when pursuing a desired result

[11].

\section{CASE BACKGROUND}

Earthquakes, hurricanes, cyclones and floods have destroyed towns and cities in Haiti for hundreds of years. On January 12, 2010, a powerful earthquake with the magnitude of 7.0 on Richter scale killed between 50,000 and 350,000 people and injured more than 1,000,000. The earthquake destroyed many basic infrastructures and buildings and made more than 1,000,000 homeless. Haitian government buildings, schools, colleges were destroyed and damaged. Haitians must be educated to adopt specific measures in addition to the building standards requirement to provide safe areas in order to minimize the damages caused by natural disasters.

\section{RESEARCH DESIGN AND PROCEDURES}

\section{Site Selection}

Interview data collection was focused on the natural disaster preparedness activities and intention to adopt cell phone which can be used in case of emergency or to share information about natural disasters. Participants were students from different universities in Haiti. The researcher has connection to these universities through the director of the Institute Aimee Cesaire. The director contacted the deans of University of Quisqueya, the State University of Haiti, School of Infotronic (ESIH), and University Institute of Quisqueya-America (INUQUA). After receiving the appropriate agreement of the deans of these colleges, a group of students were asked to visit those colleges to make appropriate contact in order to facilitate the interviews. The group of students of Institute Aimee Cesaire, met with student organizations and clubs. Together, they made a list of students who live in natural disaster zones in Haiti. The participants were contacted over phone and by e-mails. Appointments were made with the interested participants to conduct the interviews. The interviews were carried out just before the earthquake of January 12, 2010. The building that hosted the institution was destroyed.

\section{Data Collection}

The interview guide was pre-tested and approved by the deans of the colleges in Haiti. 24 students were interviewed. Participants included 7 people from University of Quisqueya, 11 people from the State University of Haiti, 3 people from the School of Infotronic (ESIH), and 3 people from the University Institute of Quisqueya-America (INUQUA).

The interviews, which lasted for about two hours, were unstructured and/or semi structured depending on participants' responses. All interviews were held in the participants' campuses and audio-recorded with the permission of the interviewees. All interviews were face-to-face and were conducted in French. At the beginning of the interviews, it was explained to the participants that there were no direct benefits for participating in this research. However participants were offered a copy of the final report of the investigation. The texts of the interviews were transcribed by the research assistants and entered into Windows Word software. The French transcripts were analyzed. The text units and excerpts were translated into English.

\section{ANALYSIS}

Content analysis is a qualitative research method frequently used in social science, sociology, education, psychology, journalism, communication science, and Information Systems [17]. The unit of analysis is 


\section{Issues in Information Systems}

Volume 13, Issue 2, pp. 11-20, 2012

fundamental in content analysis. The unit of analysis allows the researcher to break down the text into small pieces of data. The unit of analysis can be text units, sentences, words, paragraphs, etc. [15]. The researcher attaches a meaning to each unit of analysis. To carefully study our interview data, a content analysis procedure was adopted and the text unit was used as the unit of analysis. Two judges reviewed the transcripts of the interviews and identified the text units which frequently appeared and were related to the concept of preparedness activities involving the intention to adopt cell phones. The judges counted the text units and categorized them into preparedness factors and innovative characteristic factors.

\section{FINDINGS}

Some preparedness factors influencing cell phone adoption were found:

- User Previous Disaster Experience

- User Perceived Responsibility for Preparedness

- User Disaster Related Anxiety

Some innovative characteristics influencing cell phone adoption also were found:

- Perceived Relative advantage for Preparedness

- Perceived Compatibility for Preparedness

- Perceived complexity for Preparedness

- Subjective norms for Preparedness

- Perceived risks for Preparedness

Reliability Test

The reliability assessment of these findings is conducted using Cohen's kappa (k) coefficient. Cohen's kappa is a descriptive statistic for measuring agreement between two observers or judges who rate a specific unit of analysis from interview transcripts [24]. The judges use an agreement table which reflects how the ratings of the two observers agree and disagree. Agreement tables can be established in content analysis [24]. Cohen's Kappa coefficient that is greater than 0.65 is acceptable [24]. As shown in Table 1, we found Cohen's kappa reliabilities for the cell phone adoption for natural disaster preparedness factors ranged from a high of .90 to a low of .79 .

Table 1. Inter-judges reliabilities

\begin{tabular}{|l|l|}
\hline \multicolumn{1}{|c|}{ Factors } & \multicolumn{1}{|c|}{ Cohen's Kappa (k) } \\
\hline User Previous Disaster Experience & 79 \\
\hline User Perceived Responsibility for Preparedness & .89 \\
\hline User Disaster Related Anxiety & .82 \\
\hline Perceived Relative advantage for Preparedness & .90 \\
\hline Perceived Compatibility for Preparedness & .90 \\
\hline Perceived complexity for Preparedness & .86 \\
\hline Subjective norms for Preparedness & .88 \\
\hline Perceived risks for Preparedness & .85 \\
\hline
\end{tabular}




\title{
Issues in Information Systems
}

Volume 13, Issue 2, pp. 11-20, 2012

\section{DISCUSSION}

\section{User Previous Disaster Experience}

Previous disaster experience is the user's experience with natural disasters such as floods, tornadoes, lightning events, earthquakes, etc. [6]. The user can experience the disaster from hearing about it or witnessing it [6]. This experience can affect the user's life and change his vision of humanity. Over time some users can forget that episode of their life but some users may never forget those difficult moments of their existence. Those users keep see, feeling, and hearing the event in their imagination [6].

User past experiences from catastrophes can allow him to perceive relative advantage of cell phones during preparedness effort and decide to adopt a cell phone. Based on previous experience, individuals can believe on valuable sharing information in case of natural disasters. Cell phones can access the Web wirelessly [20]. So, cell phones have ability to create and share knowledge about weather conditions and natural disasters. Cell phones have substantially increased the potential for information sharing between individuals [21]. Weather forecasting technologies and resources are well advanced in developed countries. But Weather forecasting systems are not available in Haiti like in developed countries. The Haitians have to use their personal resources for preparedness. Since cell phones are an affordable technology in developing countries like Haiti, effective adoption of cell phones should contribute to the preparedness efforts in that country.

User past experiences from natural disasters also can allow him to judge the complexity of cell phones during preparedness effort and intend to adopt a cell phone with specific functionalities. This is confirmed by one of the declarations from the interviews:

\begin{abstract}
Since I was young, seniors, grandparents have told me tons of anecdotes and stories about natural disasters in Haiti... Some stories were related to how people's home or personal belongings were damaged by hurricanes, cyclones and floods at many occasions. Later on, my friends and people of my neighborhood were injured and stayed in unstable conditions for many days. Sometimes I paid visits and I feel like the same thing can happen to me... I can be in the same situation... Sometimes, it is just hard to believe or to remember. Every day, I asked myself if there is a way I can protect myself or prevent those troubles...It happens sometimes that some people do not have any tools to communicate... they do not have TVs to know about the weather forecasting... however, they have cell phones and I do not know why they do not use the cell phones.. Maybe the cell phones do not have weather related services...
\end{abstract}

\section{User Perceived Responsibility for Preparedness}

People who are responsible for vulnerable groups are likely responsible for preparedness and maybe a preparedness guidance or an appropriate source of information for preparedness. For example, children are especially vulnerable during any disaster [16]. Many humanitarian workers engaged in disaster relief believe that the needs of children are unique [16]. People who have children living at home are inclined to be well prepared for natural disasters. This is because those people feel responsible for the survival of their children. Also, McGee and Russell [13] indicated that the very young, very old, disabled, single parent households, one person households, migrants, people lacking communication and language skills, newcomers, and low income earners are likely to be associated with high levels of vulnerability to natural disasters. People who are involved in any prior preparedness activities either for their countries, government, and international organizations also bear responsibility for preparedness.

User responsibility can be expressed in terms of pressure placed on the individual to protect dependents and belongings when the natural disaster season is approaching. The level of pressure placed on an individual can also increase his intention to adopt cell phones for natural disaster preparedness. A highlight of the interviews explained that:

I received training as a natural disaster preparedness officer but the training did not emphasize the use of technology because they said telecommunication resources are usually shot down or get broken during natural disasters. But that is not the case all the time, most miracles after natural disasters are related to the use of technology... I want to do more to 


\section{Issues in Information Systems}

Volume 13, Issue 2, pp. 11-20, 2012

protect my children, my home (I have a big one)... It is a shame if people notice that I did not take a minimum precaution before the advent of natural disasters.

Responsible people like this participant adopt cell phones because cell phones can contain useful information for preparedness. The adoption of cell phones for natural disaster preparedness empowers more people to take responsibility. Therefore, responsible people and leaders should put basic information for preparedness on cell phones and free up their time to better provide emergency assistance to the community in case of natural disasters.

\section{User Disaster Related Anxiety}

Anxiety is the tendency for an individual to consider the possibility of a negative event occurring as unacceptable and threatening irrespective of the probability of its occurrence [2]. The individual keeps thinking of the probability of occurrence of natural disasters and get negative thoughts about the management of the disasters. Some individuals can panic every time they hear, see or think about natural disasters. This psychological behavior can create nightmares and fears for some individuals. Natural disaster preparedness activities can become very important for individuals who have disaster related anxiety for a future disaster. One way to combat this anxiety is the effective preparedness plan in place. For example, many people wear cell phones which can ring. People's physical presence can be detected after natural disasters by the ring of their wearable cell phones. Cell phones become consolation tools for those individuals when the natural disasters season is approaching every year. This is confirmed by one of the declarations from our interviews:

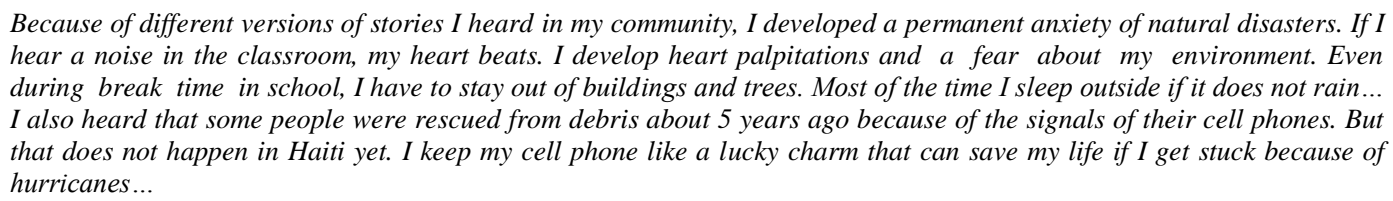

This participant shows that people believe that cell phones can help them to be rescued from the wreckage or debris. The proliferation of sensor technology adds another dimension to the importance of cell phones to search and track people presence underground after natural disasters. The sensor technology can be used to detect cell phones available in the pocket of people that are wounded or injured or become unconscious after natural disasters. That can potentially be life-saving for those people.

\section{Perceived Relative Advantage for Preparedness}

Perceived relative advantage is the advantage recognized for cell phone adoption as part of preparedness efforts before natural disasters. If it is perceived that cell phones can be used to call for help in case of natural disasters, then cell phone adoption is part of preparedness activities. Relative advantage of cell phones for preparedness can increase or decrease the user's intention to adopt a cell phone. In fact, relative advantage captures the gain from using cell phones to ask for help in comparison with that from traditional technology like telephone and fax, which are often destroyed during natural disasters. Cell phones can send a signal to locate people who are buried underground because of landslides. Sometimes cell phones can still work even underground. During natural disaster preparedness activities, perceived relative advantage of the use of cell phone can push individuals to adopt cell phones.

Cell phones can be used to guide people who are lost but still alive after natural disasters. For example, some cell phones contain an agent-based expert tourist guide for their users. This agent-based expert provides accurate information to the user by filtering it based on factors like the current location of the user, current time, and current day [20].

Data mining techniques were used to make disaster management data available online [7]. Cell phones can access via the web current and historic data that were mined to extract interesting patterns and trends [7]. The 


\title{
Issues in Information Systems
}

Volume 13, Issue 2, pp. 11-20, 2012

cell phone users can know which location is classified as safe/unsafe. A highlight of the interviews explained that:

\begin{abstract}
My cell phone can be used anywhere/anytime in case of natural disasters. I can save on my cell phone information about my health history. I know that cell phone is used for medical, business and entertainment purposes. I can save data about my identity, person to call in case of emergency... If my cell phone is still accessible after natural disasters but I am injured or the worst happens to me, rescuers can use my cell phone to provide me urgent care or identify me... I think the remote information access capacity of cell phone is advantageous and it can be taken into account in the preparedness for natural disasters.
\end{abstract}

\section{Perceived Compatibility for Preparedness}

The proliferation of cell phones raised the issue of incompatibility at two levels: incompatibility between mobile platforms and offline platform and incompatibility among mobile platforms [9]. For example, iPhone applications cannot be executed on the Android platform because of the cross-platform incompatibility problem [9]. These incompatibility issues can affect the performance of cell phones in case of natural disasters. The weather forecast information available on web sites may not be accessible on cell phones. Also information sharing during natural disasters on iPhone applications may not be accessible to Android platform users. However these incompatibility problems can be a minor issue for people in Haiti because the important information shared by people, organizations and governments for preparedness for natural disasters should be posted on all platforms simultaneously.

Another kind of incompatibility is incompatibility with cell phone services. Cell phones, which often require filling personal data, may be found incompatible with user needs during the preparedness for natural disasters. However, users who adopt the automatic form filling in their cell phones could find that compatible [19]. This is confirmed by one of the declarations from our interviews:

\begin{abstract}
During hurricanes in Haiti many people who count on cell phones panic because the kind of cell phones they have are incompatible with their lifestyle in difficult times. I think cell phones that have cookies or recall capacity can be used to find personal data forms in case of emergency due to natural disasters. So depending on my lifestyle, I adopt cell phones which fit me for natural disasters preparedness ...
\end{abstract}

\section{Perceived Complexity for Preparedness}

Tornatzky and Klein [23] find that the more complex the innovation, the lower its rate of adoption. In this research, we posit that the fear, panic and stress brought on by natural disasters may make the cell phones too complex to be used to send emergency text messages. The use of cell phones for texting requires additional cognitive and mental efforts because of the limited text input capabilities [19]. Filling out forms for web based services on cell phones is difficult and complex because it is a time consuming and frustrating task for users [19]. However that complexity is not a major obstacle to sending or receiving text messages in case of natural disasters because the amount of information a cell phone user needs to ask for help or tell his location is very small.

Some cell phones have more functionalities, applications, services and networks than others [19]. The lack of simplicity of some cell phones can become a complexity issue for cell phone users in case of natural disasters. One approach to overcome this issue is to provide context aware mobile services. Rukzio et al [19] advise to consider user context information (e.g. user location or history of selected services) to adapt applications and services accordingly. Still that advice needs to be researched when the users want to use cell phones for help in case of natural disasters. Furthermore, as the cell phones are very user friendly with their graphical user interface, touch screen and voice recognition, it is likely that potential Haitian may feel that cell phones are less complex to use, and hence would be likely to use such services to recover after natural disasters. This is confirmed by one of the declarations from our interviews: 


\section{Issues in Information Systems}

Volume 13, Issue 2, pp. 11-20, 2012

comfortable with cell phones' functionalities. That may have something to do with their knowledge, but I do not know. Most people use cell phones for just making phone calls. They underestimate other functionalities of cell phones because they are difficult to use or to recall. There are many people among my neighbors who always request help before using cell phones for other purposes than making a simple call... Some of my fellow countrymen should adopt cell phones because they do not need to dial a number or scroll through the cell phone's contact list before using it; all they need is just a simple voice recognition function. I found that impressive because cell phones can still transmit any noise or movement you make if you are injured to people from remote area and that is enough to attract their attention...

\section{Subjective Norms for Preparedness}

Subjective norms are the perceived pressures on an individual to execute a given behavior and the individual's willingness to comply with those pressures [5]. The DOI theory shows that subjective norms perform significant functions in the adoption decision of an individual [10]. Therefore, subjective norms can be used to enhance the understanding of user's adoption behavior [10].

Individuals may believe that family members, friends, colleagues and peer groups favor certain behaviors, and their beliefs influence their behavioral intentions [25]. Our participants know that family members, friends and groups of pressure adopt cell phones as part of natural disaster preparedness efforts. Therefore individuals' beliefs influence their intention to adopt cell phones. Because individuals hear testimonies from natural disaster survivors about the utility of cell phones, they are likely to adopt cell phones. A highlight of the interviews explained that:

I have relatives who lost everything they possess including their home because of natural disasters. They were out of town during the time of the disaster. What I do not understand is most people of their community used wood panels and other materials to protect their house and they did not lose much... If they had cell phones, they may have called their neighbors and told them that they were out of town and they needed help. I intend to have a cell phone with me because I do not want to be in the same situation as some of my relatives who did not use cell phones to call for help. I do not want to regret... I do not want be a negative role model as one of those people who lost everything because they do not want to follow other people's advice or do what their friends, relatives usually do to avoid this.

\section{Perceived Risks for Preparedness}

Based on the conclusion of prior studies, Greening et al [6] reported that victims and survivors of natural disasters tend to report elevated risk estimates for future negative life events. They mentioned that people may use their personal experience with events as a standard by which to assess risks. Based on the literature on judgments made by victims, They found that there was a simulation heuristic (imagery) as a mediator for the relation. Imagery is cognitive images of personal involvement in the natural disaster. They defined perceived personal risk as the likelihood of an event occurring to oneself. Individuals who have experienced natural disasters are likely to adopt the cell phone because they expect disaster can happen again. A highlight of the interviews explained that:

\footnotetext{
My parents have homes, farms, and a lucrative business. They will make any arrangement to protect their asset against natural disasters. This is because they do not want to take any risk. Absolutely, they should be more than happy to adopt cell phones. As long as, cell phones adoption can potentially help my parents to minimize the loss or damage in case of natural disasters. My parents are usually well prepared for natural disasters because they feel responsible and they have more experience than people I know who do not have anything to loose.
}

\section{CONCLUSION}

This research reports on the preparedness factors influencing the intention to adopt cell phones in natural disaster countries. Haitian Republic has been chosen because it has a long history of natural disasters which affect the country many times a year. As a country at high risk which is one of the most populated areas in West Indies, appropriate natural disaster preparedness and emergency plan must be implemented. Interview data was collected from 24 students of four Haitian colleges and universities located in Port-au- Prince, the capital of Haiti. Those students lived in high risk of natural disaster zones and have some experiences with the cell phone use and are able to buy cell phones. 


\section{Issues in Information Systems}

Volume 13, Issue 2, pp. 11-20, 2012

A review of the natural disaster literature suggests that there are physical, organizational, individual, contextual, socio-demographic and psychological factors associated with natural disaster preparedness. In the same vein, Rogers' IT adoption factors were reviewed and found to be connected to the individual intention to adopt cell phones.

Some preparedness factors influencing cell phone adoption were found: user previous disaster experience, user perceived responsibility for preparedness and user disaster related anxiety. Some innovative characteristics influencing cell phone adoption also were found: perceived relative advantage for preparedness, perceived compatibility for preparedness, perceived complexity for preparedness, subjective norms for preparedness and perceived risks for preparedness.

In developing countries which are vulnerable to natural disasters, individuals, local and international organizations, and emergency responses management agencies considering cell phone adoption in their natural disaster preparedness plans will be successful. This study should allow those entities to inform individuals living in natural disaster zones about the importance of the use of technology to survive and quickly recover after natural disaster events.

\section{REFERENCES}

1. Baker, E. J. (2011). Household preparedness for the Aftermath of Hurricanes inFlorida, Applied Geography, 31, 46-52.

2. Carleton, R. N., Collimore, K. C., \& Asmundson, J. G. J. (2010). It's not just the judgements-It's that I don't know: Intolerance of uncertainty as a predictor of social anxiety, Journal of Anxiety Disorders, 24, 189-195.

3. Crowther, K. J. (2010). Risk-informed assessment of regional preparedness: A case study of emergency potable water for hurricane response in Southeast Virginia, International Journal of Critical Infrastructure Protection, 3, 83-98.

4. Enqvist, H. (2005). Preparedness of households and catering establishments for incidents involving radioactive contamination, Journal of Environmental Radioactivity, 83, 415-419.

5. Fishbein, M., \& Ajzen, I. (1975). Beliefs, attitude, intention, and behavior: An introduction to theory and research. Boston: Addison-Wesley

6. Greening, L., Dollinger, S. J., and Pitz, G., (1996). Adolescents' perceived risk and personal experience with natural disasters: An evaluation of cognitive heuristics, Acta Psyehologica, 91, 27- 38.

7. Hristidis, V., Chen, S-C., Li, T., Luis, S., \& Deng, Y. (2010). Survey of data management and analysis in disaster situations, The Journal of Systems and Software, 83, 1701-1714.

8. Hui Min Lee, C., Cheng, Y. W., and Depickere, A. (2003). Comparing smart card adoption in Singapore and Australian universities, Int. J. Human-Computer Studies, 58, 307-325.

9. Kao, Y-W, Lin, C. F., Yang, K. A., \& Yuan, S. M. (2012). A Web-based, Offline- able, and Personalized Runtime Environment for executing applications on mobile devices, Computer Standards \& Interfaces, 34, 212-224.

10. Kim, H-B., Kim, T., and Shin, S. W. 2009. Modeling roles of subjective norms and eTrust in customers' acceptance of airline B2C eCommerce websites. Tourism Management, 30, 266-277.

11. Lee, M-C. (2009). Factors influencing the adoption of internet banking: An integration of TAM and TPB with perceived risk and perceived benefit, Electronic Commerce Research and Applications, 8, 130141.

12. Manca D. \& Brambilla, S. (2011). A methodology based on the Analytic Hierarchy Process for the quantitative assessment of emergency preparedness and response in road tunnels, Transport Policy, 18, $657-664$.

13. McGeea, T. K. \& Russell, S., (2003). It's just a natural way of life an investigation of wildfire preparedness in rural Australia, Environmental Hazards, 5, 1-12

14. Miceli, R., Sotgiu, I, \& Settanni, M, (2008). Disaster preparedness and perception of flood risk: A study in 


\section{Issues in Information Systems}

Volume 13, Issue 2, pp. 11-20, 2012

an alpine valley in Italy, Journal of Environmental Psychology,28, 164-173.

15. Nasir, S. (2005). The development, change, and transformation of Management Information Systems (MIS): A content analysis of articles published in business and marketing journals, International Journal of Information Management, 25, 442-457.

16. Olness, K., Sinha, M., Herran, M., Cheren, M., and Pairojkul, S. ( 2005). Training of Health Care Professionals on the Special Needs of Children in the Management of Disasters: Experience in Asia, Africa, and Latin America, Ambulatory Pediatrics, 5, 244248.

17. Qu, Z., Zhang, H. \& Li, H. ( 2008). Determinants of online merchant rating: Content analysis of consumer comments about Yahoo merchants, Decision Support Systems, 46, 440-449.

18. Rogers, E.M., 1983. Diffusion of Innovations, The Free Press, New York.

19. Rukzioa, E., Nodab, C., De Lucac, A., Hamardd, J., Coskunc, F. (2008). Automatic form filling on mobile devices, Pervasive and Mobile Computing, 4, 161-181.

20. Serif, T. and Ghinea, G. (2008). Mobile information access in the real world: A story of three wireless devices, Computers in Human Behavior, 24, 1385-1403.

21. Shin, S. K., Ishman, M., Sanders, G. L., (2007). An empirical investigation of socio- cultural factors of information sharing in China. Information \& Management, 44, 165-174.

22. Tompkins, E. L. (2005). Planning for climate change in small islands: Insights from national hurricane preparedness in the Cayman Islands, Global Environmental Change, 15, 139-149.

23. Tornatzky, L.G. \& Klein K. J. (1982). Innovation characteristics and innovation adoptionimplementation: a meta-analysis of findings, IEEE Transactions on Engineering Management, (29:11), 2845.

24. Warrens, M. J. (2011). Weighted kappa is higher than Cohen's kappa for tridiagonal agreement tables, Statistical Methodology, 8, 268-272

25. Yang, K., \& Jolly, L. D. (2009). The effects of consumer perceived value and subjective norm on mobile data service adoption between American and Korean consumers, Journal of Retailing and Consumer Services, 16, 502-508. 